\title{
Geochemistry and geochronology of the Méiganga metadiorite: implications on the timing of D2 deformational phase in Adamawa Yadé Domain in Cameroon
}

\author{
A. A. GANWA ${ }^{1 *}$, W. SIEBEL ${ }^{2}$, W. FRISCH ${ }^{2}$, C. K. SHANG $^{2}$ and \\ G. E. EKODECK ${ }^{3}$
}

${ }^{1}$ Department of Earth Sciences, University of Ngaoundéré, P.O. Box 454 Ngaoundéré, Cameroon.

${ }^{2}$ Department of Earth Sciences, University of Tübingen, Sigwartstr, 10, D72076 Tübingen, Germany. ${ }^{3}$ Department of Earth Sciences, University of Yaoundé I, P.O. Box 872 Yaoundé, Cameroon.

*Corresponding author, E-mail: ganwal@yahoo.fr; Tel: 23777413214

\begin{abstract}
The metadiorite of Méiganga forms an ovoid body intruding metasedimentary gneisses in the area of Méiganga city. It shows schistosity, banded structure and is made up of green hornblende, biotite, antiperthitic plagioclase, quartz, zircon, opaque minerals and chlorite. Imprints of D2, D3 and D4 deformation phases are identical in the metadiorite and the amphibole biotite gneiss, leaving no doubt as to the syn-D2 emplacement and crystallization of the protolith of the metadiorite. The metadiorite samples display high-K calc-alkaline to shoshonitic characteristics and possess features of I-type granitoids. They exhibit relative low enrichment of LREE with respect to HREE, $(\mathrm{La} / \mathrm{Yb})_{\mathrm{N}}=9.5-11.3$, and moderate negative Eu anomalies $(\mathrm{Eu} / \mathrm{Eu} *=0.80-0.83)$. Optical features of the zircon grains of the metadiorite and its syn-D2 emplacement and crystallisation indicate that the zircon evaporation ${ }^{207} \mathrm{~Pb} /{ }^{206} \mathrm{~Pb}$ ages $(614.1 \pm 3.9 \mathrm{Ma}$ and $619.8 \pm 9.8 \mathrm{Ma})$ of this rock date the D2 deformation phase in the Méiganga area. Comparison with other sectors of the Adamawa Yadé Domain (AYD) shows the close synchronic character of the D2 deformational phase in central Cameroon (Méiganga, Tibati, Ngaoundéré areas) and the diachronic character of this phase in central and western Cameroon. We found that a similar chronological evolution has been demonstrated in the Macururé Domain of the Sergipano Belt (NE Brazil).
\end{abstract}

(C) 2011 International Formulae Group. All rights reserved.

Keywords: syn-D2 granitoid; ${ }^{207} \mathrm{~Pb} /{ }^{206} \mathrm{~Pb}$ age; Central Pan-Africa Fold Belt; Sergipano Belt.

\section{INTRODUCTION}

The main structural feature of the Central Africa Fold Belt (CAFB) is the presence of regional transcurrent shear zones. These unconformities have been used to fix the boundaries between different domains of the belt: the Tcholliré-Banyo shear zone (TBSZ) is considered as border between the west Cameroon domain (WCD) and the Adamawa-Yadé domain (AYD), whilst the
Sanaga shear zone (SSZ) separates the AYD from the Yaoundé domain (YD) (Toteu et al., 2004) (Figure 1). In Cameroon, those unconformities have also been used to differentiate the Panafrican basement into a northern, central and southern domain (Nzenti, 1994).

The AYD is characterised by the widespread occurrence of granitoids, which have been classified according to deformation 
state into syn-tectonic, late tectonic and posttectonic intrusives (Lassere, 1961; Toteu et al., 2001). Syn-tectonic metadiorites are widely distributed in the cameroonian portion of the AYD. The basement of the AYD consists of Paleoproterozoic metasedimentary rocks and orthogneisses which are preserved as remnants in the Mbé and Méiganga areas (Penaye et al., 1989; Ganwa, 2005). Detailed petrographic and geochronologic studies exist for a few plutons in the southwestern part of the AYD (Nguiessi Tchankam et al., 1997; Tagne-Kamga et al., 1999; Tagne-Kamga, 2003; Nzolang et al., 2003; Djouka Fonkwé et al., 2007). In the Tibati area in central Cameroon, and in western Cameroon, few syn-kinematic plutons crop out in close vicinity to the Panafrican Adamawa ductile shear zone (Central Cameroon Shear Zone: CCSZ; Nzenti et al., 2006; Njanko et al., 2006, 2010; Kwekam et al., 2010). They are high-K calc-alkaline plutons and show geochemical similarities to other Panafrican high-K calc-alkaline syn-kinematic plutons from western Cameroon. Three main successive tectonic events associated with the Panafrican collisional and post-collisional evolution are identified in Cameroon: (i) crustal thickening (ca. 630-620 Ma); (ii) left lateral wrench movement (ca. 613-585 Ma), and (iii) right lateral wrench movement (ca. 585-540 Ma) (Ngako et al., 2008).

This paper presents the results of geochemistry and a single zircon $\mathrm{Pb}$ evaporation study of a metadiorite from the Méiganga area. The aim was to constrain the age of the D2 deformation in the study area and, on a larger scale, to characterize its evolution in the AYD, given that the D2 is the most important deformational phase in the Panafrican metamorphic history in Central Africa.

\section{MATERIALS AND METHODS Analytical methods}

Major and trace elements were analysed by X-ray fluorescence (XRF) at the University of Tübingen, Germany. Rare-earth elements were analysed by Inductively Coupled
Plasma-Atomic Emission Spectrometry (ICPAES) at the CRPG (Centre de recherches pétrographiques et géochimiques, Vandoeuvre-lès-Nancy, France). Analytical precisions are typically better than $2 \%$ for major elements except for $\mathrm{P}$ and $\mathrm{Mn}$ which have precisions better than $15 \%$, and $5-10 \%$ for most trace elements. Zircon grains were separated from the 63-200 $\mu \mathrm{m}$ sieved rock fractions by standard separation techniques (milling, wet shaking table, magnetic and heavy liquid separation) and finally handpicking under the binocular microscope. Cathodoluminescence images were performed on an electronic microscope LEO Model 1450 VP (variable pressure) 4-Quadrant BSEDetector working with an accelerating voltage of $10 \mathrm{kV}$. For zircon $\mathrm{Pb}$ evaporation, single zircon grains were analysed using a double Re filament configuration. Principles of the evaporation method were described by Kober (1986, 1987). Measurements were done using a Finnigan MAT 262 mass spectrometer equipped with a MassCom ion counter at the University of Tübingen. All ${ }^{207} \mathrm{~Pb} /{ }^{206} \mathrm{~Pb}$ ratios were corrected for common $\mathrm{Pb}$ according to Cocherie et al. (1992), and the error for a single zircon age was calculated after Siebel et al. (2005). Repeated measurements on natural zircon from Phalaborwa, South Africa (Kröner and Willner, 1998), and from zircon standard 91500 of 'Kuehl Lake' (Canada) (Wiedenbeck et al., 1995) were performed for geologically realistic age and error treatment (Chen et al., 2002). The results were similar to those obtained by previous authors (Kröner and Willner, 1998; Wiedenbeck et al., 1995).

Petrography and structural characteristics
of the metadiorite
The metadiorite constitutes the
basement of Méiganga town and its
neighbourhood (Figure 2). It forms an ovoid
body stretching in NE-SW direction. The
magmatic body intrudes amphibole biotite
gneisses (ABGn) and spatially associated to
pyroxene-amphibole-biotite granites (PABGr)
and biotite-muscovite granites (BMGr). With 


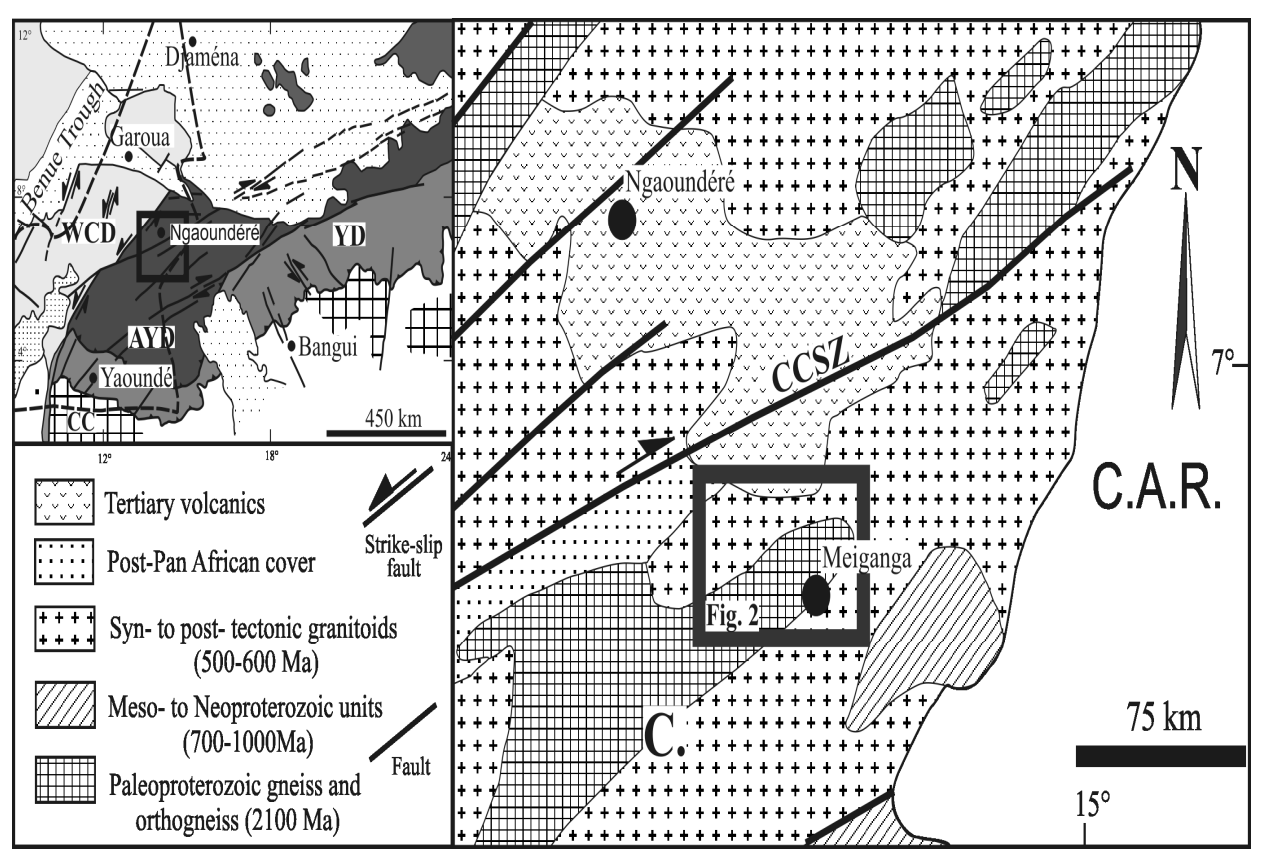

Figure 1: Geological sketch map of East Adamawa showing the Méiganga area.

Patterns are as follows: grids, Congo craton (CC); dark grey; Adamawa-Yadé Domain (AYD); medium grey, Yaoundé Domain (YD); light grey, West Cameroon Domain (WCD); Central Cameroon Shear Zone (CCSZ); heavy dots, Cameroon Line; light dots, Mesozoic sediments. The square in the inset localizes the large figure. Cameroon (C.), Central African Republic (C.A.R.)

respect to the state of deformation, the granites are posterior to the metadiorite. Studies on the various host rocks have been performed by Ganwa (2005).

The metadiorite is medium grained and shows a schistosity and a banded structure defined by quartzofeldspathic layers as a result of migmatization. Plagioclase is antiperthitic and contains submicroscopic inclusions. Quartz is partly recrystallised and forms polycrystalline ribbons parallel to the schistosity. Chlorite and opaque minerals are formed at the expense of biotite.

The metadiorite has been affected by three deformation phases (D2, D3, D4), contrary to the host gneisses which were also affected by D1. The metadiorite shows a penetrative $\mathrm{S} 2$ foliation marked by alternation of ferromagnesian minerals (biotite, amphibole) and quartzofeldspathic minerals. $\mathrm{S} 2$ in the metadiorite is parallel to $\mathrm{S} 2$ in the host gneisses with few exceptions. It dips between $30^{\circ}$ and $90^{\circ}$ towards NW to $\mathrm{N}$ or $\mathrm{S}$ to SE (Figure 2). The L2 lineation is characterized by stretching of quartz, elongate aggregates of quartz and feldspar, and the alignment of amphibole and biotite. L2 has a weak to moderate angle of plunge (up to $40^{\circ}$ ) towards NE or SW. Moreover, it shows the same orientation as in the host gneisses (Figure 2).

In the metadiorite and the host gneisses, D3 is represented by folds (F3) and an axial plane foliation (S3). The folds also affected the granite dykes. It is likely that previous schistosity planes were transposed by S3 and behave as composite S2/S3 surface.

The last deformation phase D4 was brittle. This phase produced joints and faults present at outcrop scale in all rock types. The faults are normal dextral strike-slip faults. They indicate a NE-SW distensional movement. 




Figure 2: Geological map of Méiganga area showing stereonet of structural data in metadiorite and amphibole biotite gneiss.

(1) basalt, (2) conglomerate, (3) biotite-muscovite granite, (4) pyroxene-amphibole-biotite granite, (5) Metadiorite, (6) amphibole-biotite gneiss, (7) amphibolite, (8) pyroxene-amphibole gneiss, (9) mylonite, (10) dolerite, (11, 12) schistosity, $(13,14)$ lineations, (15) fractures, (16) fault, (17) supposed fault, (18) rivers, (19) road, (20) path. In the stereonet: filled circle $=$ S2 pole, open circle with line: $\mathrm{L} 2$ lineation. Double arrow represents the strike of axial plane of the regional F3 fold.

The lack of the D1 imprint in the metadiorite indicates that its emplacement post-dates this deformational phase. The tectonic transposition of the D1 phase by the second phase of deformation does not allow to precise its orientation. At map scale (Figure 2), the metadiorite shows an elongated shape parallel to the orientation of the L2 lineation and to the S2 schistosity strike; this points to the syn-D2 emplacement of the magmatic body. Furthermore, the intense solid state deformation of the metadiorite and the fact that it shows the same structural characteristics as the gneiss, with respect to the D2 phase implies that the metadiorite was emplaced during the D2 deformational phase. Following D2, the metadiorite and the host gneisses experienced the same structural evolution; the distribution of S2 poles in the stereonet display, both in the metadiorite and the gneisses, regional folds with NE-SW trending axes (Figure 2). The orientation of D1 is difficult to determine; it could correspond to the N-S kinematic direction during the early Panafrican tectonic evolution which includes thrusting and shortening leading to crustal thickening (Ngako et al., 2008). The regional main strain direction during the D2 deformational phase was NE$\mathrm{SW}$ as revealed by the orientation of the L2 stretching lineation. As the D3 is concerned, the major stress is orientated NW-SE, perpendicular to the regional $\mathrm{F} 3$ axial plane. 


\section{RESULTS}

Geochemistry geochronology

and ${ }^{207} \mathbf{P b} /{ }^{206} \mathbf{P b}$

Chemical data of representative metadiorite samples are presented in Table 1. $\mathrm{SiO}_{2}$ contents range from 46 to $66 \mathrm{wt} \%$. In the $\mathrm{SiO}_{2}$ versus $\left(\mathrm{Na}_{2} \mathrm{O}+\mathrm{K}_{2} \mathrm{O}\right)$ diagram (Figure $3 \mathrm{a}$ ), the samples were scattered but are mainly plotted in the fields of diorite and quartz diorite. The $\mathrm{Na}_{2} \mathrm{O} / \mathrm{K}_{2} \mathrm{O}$ ratio varies between 1.35 and 2.55 with the exception of samples Me1b and Me1c which show ratios of 0.20 and 0.45 , respectively. The metadiorite samples define a medium- to high- $\mathrm{K}$ calcalkaline suite (again with the exception of samples Meb1 and Me1c with plots in the shoshonitic field in Figure $3 \mathrm{~b}$ ). ASI (A/CNK $\left.=\left[\mathrm{Al}_{2} \mathrm{O}_{3} /\left(\mathrm{CaO}+\mathrm{Na}_{2} \mathrm{O}+\mathrm{K}_{2} \mathrm{O}\right) \mathrm{mol} \%\right]\right)$ (Table 1) varies from 0.6 to 0.9 , pointing to an I-type character (White and Chappell, 1977).

The studied samples showed a wide variation of trace element contents $(\mathrm{Ni}$ : 17-70 ppm; Cr: 66-178 ppm; Y: 22-62 ppm; Pb: 8.824 ppm; Rb: 40-108 ppm; Sr: 188-630 ppm; Ba: $935-1424 \mathrm{ppm}$ ). The $\mathrm{K} / \mathrm{Rb}$ ratio is 775 for Me1b and between 201 and 374 for the other samples, and the $\mathrm{Rb} / \mathrm{Sr}$ ratio was less than 0.6. Normalized trace element and REE patterns are shown in Figure 4. The samples displayed negative anomalies in $\mathrm{Nb}, \mathrm{Ta}$, and $\mathrm{Ti}$ and a positive anomaly in $\mathrm{K}$ (Figure 4a). They exhibited moderate enrichment in LREE with respect to HREE (Figure $4 b):(\mathrm{La} / \mathrm{Yb})_{\mathrm{N}}=9.5$
- 11.3, $(\mathrm{La} / \mathrm{Sm})_{\mathrm{N}}=2.8-3.0,(\mathrm{Gd} / \mathrm{Yb})_{\mathrm{N}}=1.9-$ 2.1 and had moderate negative Eu anomalies $\left(\mathrm{Eu} / \mathrm{Eu}^{*}=0.80-0.83\right)$ and similar total REE concentrations $\left(\sum \mathrm{REE}=174-195 \mathrm{ppm}\right)$.

Photographs and CL images of representative zircon grains of the metadiorite are shown in Figure 5a. The zircons are euhedral to subhedral in shape with euhedral oscillatory zonation and high-luminescence rims in some grains. They showed no obvious core domains and revealed many inclusions, probably of Th-rich minerals such as thorite $\left(\mathrm{ThSiO}_{4}\right)$ or thorianite $\left[(\mathrm{Th}, \mathrm{U}) \mathrm{O}_{2}\right]$. The results of $\mathrm{Pb}$ evaporation of representative zircon grains are shown in Tables $2 a$ and $2 b$. U/Th ratios varied from one grain to another and from one heating step to another. With the exception of two grains (3 and 6 of sample $\mathrm{Me}$ ), the U/Th ratios generally increased with increasing heating temperature. In contrast, sample ZGo1 showed a decrease of the U/Th ratio in the higher heating steps. The ${ }^{204} \mathrm{~Pb} /{ }^{206} \mathrm{~Pb}$ ratios were generally $<0.001$. The ${ }^{207} \mathrm{~Pb} /{ }^{206} \mathrm{~Pb}$ ages ranged from $601.3 \pm 0.8 \mathrm{Ma}$ to $628.9 \pm 4.7 \mathrm{Ma}$. In sample ZGo1, the ${ }^{207} \mathrm{~Pb} /{ }^{206} \mathrm{~Pb}$ ages ranged from $582.1 \pm 7.8 \mathrm{Ma}$ to $633.2 \pm 3.9 \mathrm{Ma}$. There is a good reproducibility of the ${ }^{207} \mathrm{~Pb} /{ }^{206} \mathrm{~Pb}$ ages of the different heating steps, which allowed the determination of weighted mean ages of 614.1 $\pm 3.9 \mathrm{Ma}$ (sample Me) and $619.8 \pm 9.8 \mathrm{Ma}$ (sample ZGo1) (Figure 5b, 5c; Table 2a, 2b).

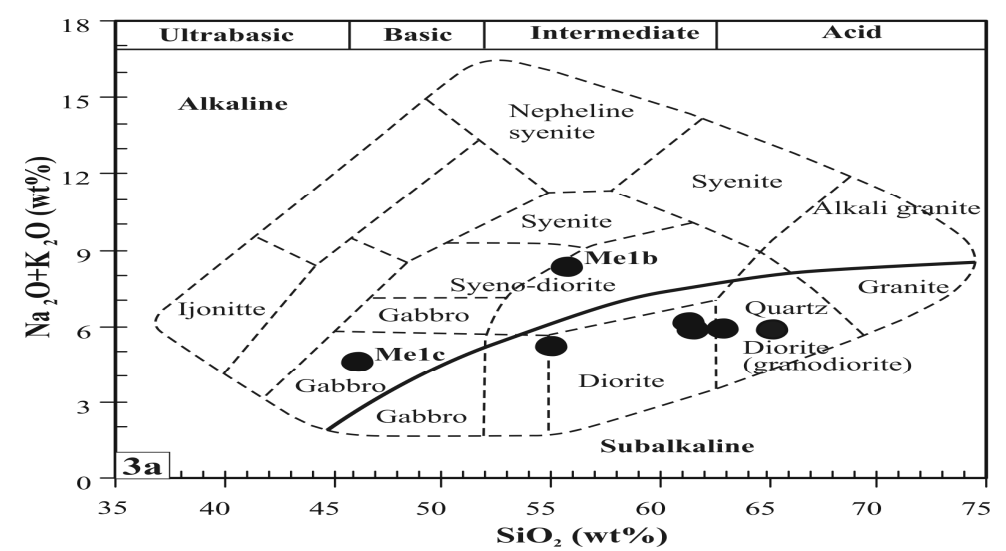

Figure 3a: Classification of the studied samples in the $\mathrm{SiO}_{2}$ vs $\mathrm{K}_{2} \mathrm{O}$ diagram (Wilson, 1989). 


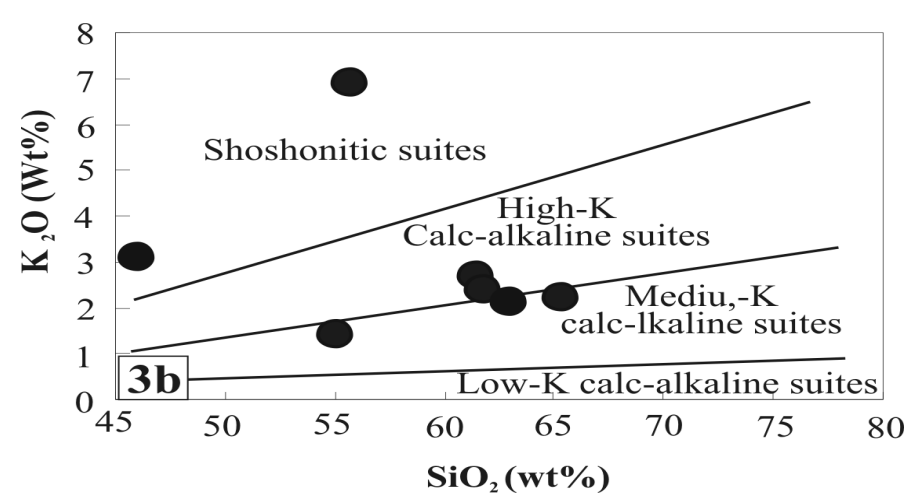

Figure 3b: Distribution of the Méiganga metadiorite samples in the $\mathrm{K}_{2} \mathrm{O}$ versus $\mathrm{SiO}_{2}$ diagram with compositional domains of the different calc-alkaline series, after Rickwood (1989).

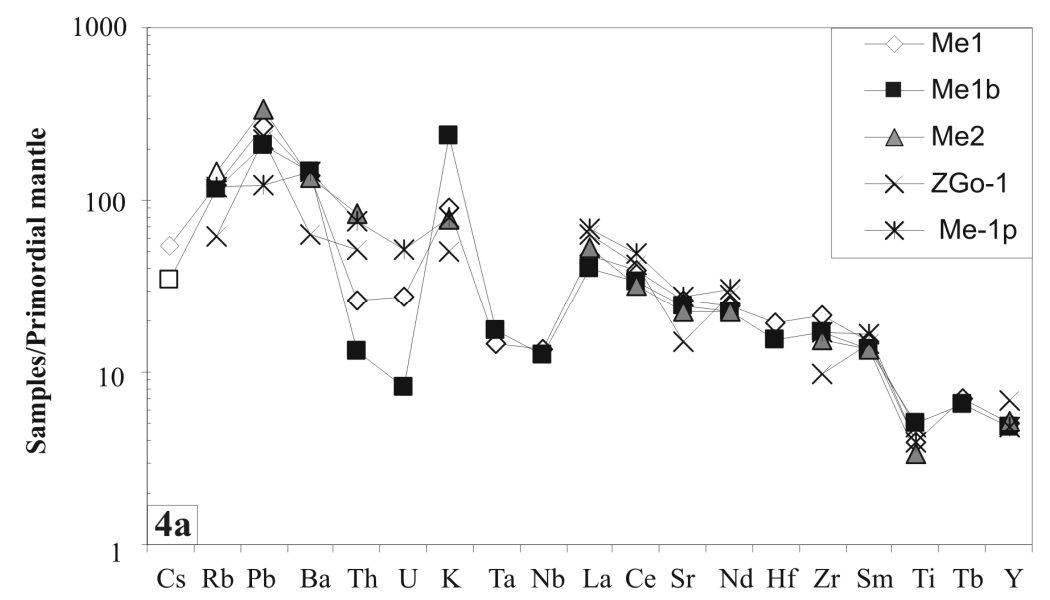

Figure 4a: Primordial normalised trace elements pattern for the metadiorite of Méiganga. Normalisation values are from Mc Donough et al. (1992).

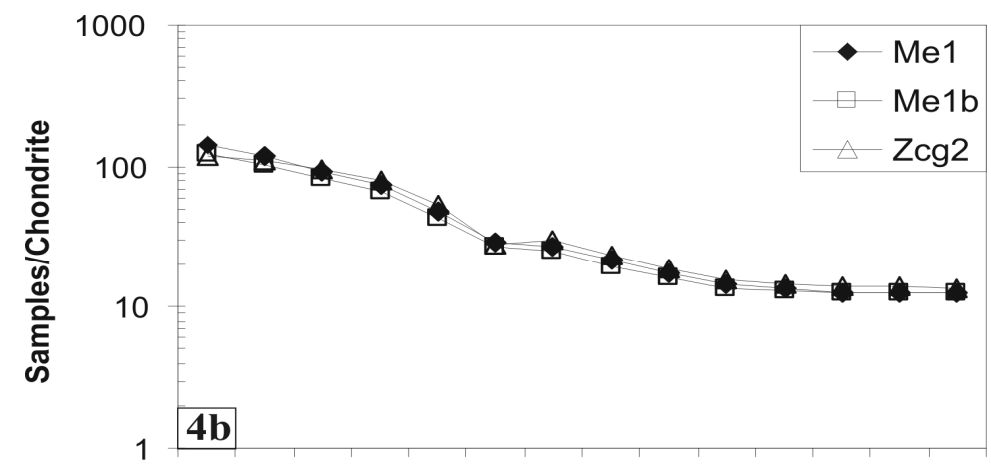

La Ce Pr Nd Sm Eu Gd Tb Dy Ho Er Tm Yb Lu

Figure 4b: Chondrite-normalised REE pattern for the Méiganga metadiorite. Normalisation values are from Mc Donough and Sun (1995). 

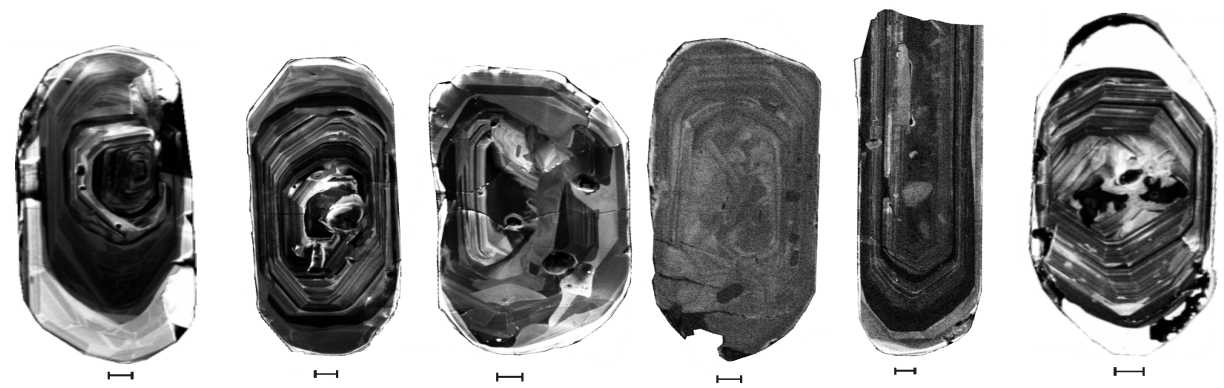

Figure 5a: Cathodoluminescence images of representative zircon crystals of the metadiorite (sample Me). Scale bar corresponds to $20 \mu \mathrm{m}$.
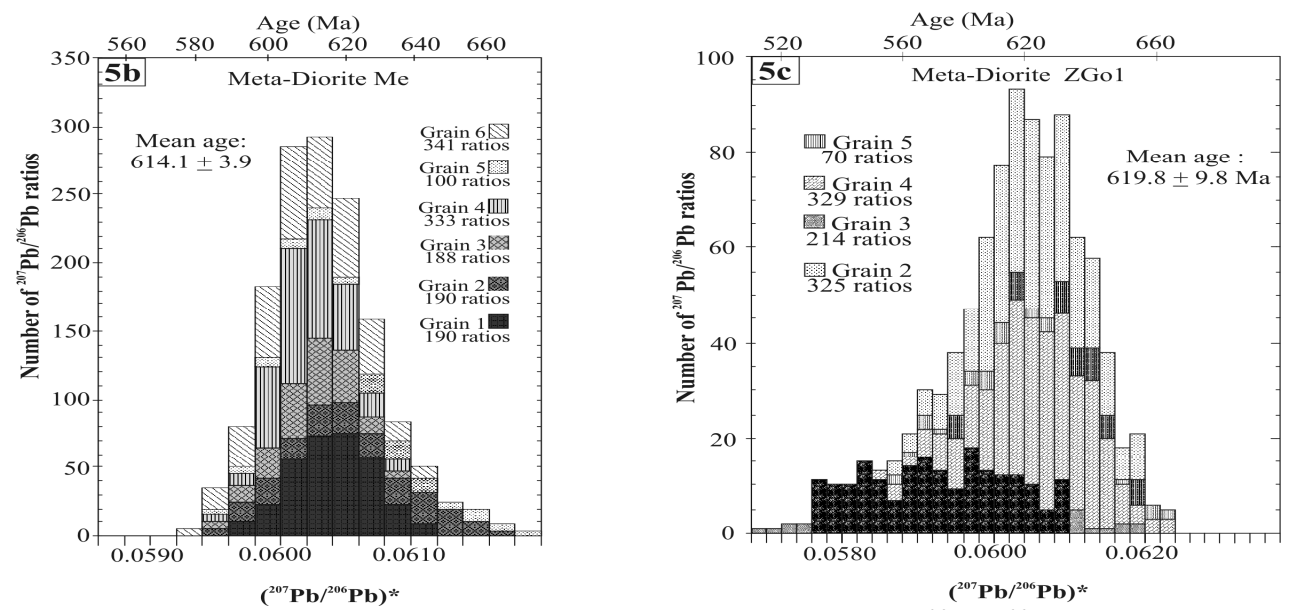

Figure 5b and 5c: Histograms showing the distribution of radiogenic ${ }^{207} \mathrm{~Pb} /{ }^{206} \mathrm{~Pb}$ ratios obtained from evaporation analyses of zircons grains (5b: sample Me, 5c: sample ZGo1).

Table 1: Geochemical composition of the Méiganga metadiorite.

\begin{tabular}{llllllll}
\hline Rock type & & \multicolumn{7}{c}{ Metadiorite } \\
\hline Samples & Me1 & Me1b & Me2 & ZGo-1 & Me-1p & Me1c & Yob1 \\
\hline $\mathrm{SiO}_{2}$ & 61.442 & 55.659 & 65.247 & 55.01 & 61.72 & 46.113 & 62.934 \\
$\mathrm{TiO}_{2}$ & 0.846 & 1.066 & 0.722 & 1.04 & 0.83 & 1.852 & 0.61 \\
$\mathrm{Al}_{2} \mathrm{O}_{3}$ & 16.23 & 13.44 & 15.38 & 16.36 & 16.41 & 12.47 & 14.23 \\
$\mathrm{Fe}_{2} \mathrm{O}_{3}$ & 6.688 & 7.978 & 5.366 & 9.20 & 6.00 & 16.443 & 6.671 \\
$\mathrm{MnO}$ & 0.121 & 0.122 & 0.103 & 0.16 & 0.11 & 0.285 & 0.115 \\
$\mathrm{MgO}$ & 3.31 & 4.41 & 2.60 & 4.18 & 3.10 & 7.91 & 2.49 \\
$\mathrm{CaO}$ & 5.40 & 6.35 & 4.48 & 7.75 & 5.18 & 7.85 & 6.21 \\
$\mathrm{Na} 2 \mathrm{O}$ & 3.54 & 1.40 & 3.57 & 3.69 & 3.57 & 1.40 & 3.78 \\
$\mathrm{~K}_{2} \mathrm{O}$ & 2.60 & 6.92 & 2.27 & 1.45 & 2.33 & 3.13 & 2.10 \\
$\mathrm{P}_{2} \mathrm{O}$ & 0.25 & 2.09 & 0.192 & 0.23 & 0.24 & 0.537 & 0.688 \\
$\mathrm{LOI}$ & 0.51 & 0.73 & 0.41 & 0.42 & 0.70 & 0.86 & 0.43 \\
$\mathrm{Sum}$ & 101.16 & 101.21 & 100.56 & 99.66 & 100.42 & 99.12 & $100 . .65$ \\
$\mathrm{Na}_{2} \mathrm{O}+\mathrm{K}_{2} \mathrm{O}$ & 6.14 & 8.32 & 5.84 & 5.14 & 5.90 & 4.53 & 5.88 \\
$\mathrm{Na}_{2} \mathrm{O} / \mathrm{K}_{2} \mathrm{O}$ & 1.36 & 0.20 & 1.57 & 2.54 & 1.54 & 0.45 & 1.80 \\
$\mathrm{~A} / \mathrm{CNK}$ & 0.9 & 0.6 & 0.9 & 0.8 & 0.9 & 0.6 & 0.7 \\
& & & 1760 & & & &
\end{tabular}


A. A. GANWA et al. /Int. J. Biol. Chem. Sci. 5(4): 1754-1767, 2011

\begin{tabular}{|c|c|c|c|c|c|c|c|}
\hline Mg\# & 0.50 & 0.52 & 0.49 & 0.47 & 0.51 & 0.90 & 0.87 \\
\hline $\mathrm{Ba}$ & 966 & 1012 & 936 & 447 & 1009 & 935 & 1424 \\
\hline $\mathrm{Co}$ & 21.2 & 41.3 & 15.7 & 28.1 & 18.7 & 44.6 & 58.9 \\
\hline $\mathrm{Cr}$ & 81.8 & 162.1 & 126.4 & 163.0 & 65.8 & 177.7 & 124.4 \\
\hline $\mathrm{Ni}$ & 30.1 & 70.0 & 54.0 & 44.7 & 17.3 & 56.1 & 60.9 \\
\hline $\mathrm{Rb}$ & 77.74 & 74.06 & 93.5 & 39.7 & 75.3 & 107.50 & 46.70 \\
\hline $\mathrm{Sr}$ & 556 & 513 & 469 & 313 & 576 & 187 & 630 \\
\hline V & 135.5 & 138.1 & 104.0 & 215.2 & 118.2 & 347.6 & 97.3 \\
\hline $\mathrm{Y}$ & 22.9 & 21.8 & 23.6 & 30.9 & 22.0 & 61.8 & 29.1 \\
\hline $\mathrm{Zn}$ & 90.1 & 94.7 & 64.1 & 110.3 & 73.9 & 208.7 & 73.2 \\
\hline $\mathrm{Zr}$ & 237 & 189 & 172 & 108 & 189 & 265 & 323 \\
\hline K & 21574 & 57426 & 18859 & 12044 & 19308 & 25965 & 17465 \\
\hline $\mathrm{La}$ & 34.01 & 28.66 & 37.90 & 45.0 & 48.4 & 42.0 & 102.6 \\
\hline $\mathrm{Ce}$ & 71.81 & 62.42 & 59.0 & 77.9 & 91.4 & 124.6 & 198.6 \\
\hline $\operatorname{Pr}$ & 8.58 & 7.67 & & & & & \\
\hline $\mathrm{Nd}$ & 33.38 & 30.47 & 30.6 & 38.2 & 42.1 & 72.1 & 71.5 \\
\hline $\mathrm{Sm}$ & 6.60 & 6.03 & 6.0 & 6.5 & 7.3 & 10.6 & 11.3 \\
\hline $\mathrm{Eu}$ & 1.61 & 1.53 & 1.4 & 1.4 & 1.8 & 1.6 & 2.2 \\
\hline $\mathrm{Gd}$ & 5.26 & 4.91 & & & & & \\
\hline $\mathrm{Tb}$ & 0.77 & 0.71 & & & & & \\
\hline Dy & 4.27 & 4.01 & & & & & \\
\hline Ho & 0.79 & 0.75 & & & & & \\
\hline $\mathrm{Er}$ & 2.18 & 2.11 & & & & & \\
\hline $\mathrm{Tm}$ & 0.31 & 0.31 & & & & & \\
\hline $\mathrm{Yb}$ & 2.05 & 2.04 & 2 & 2.9 & 1.8 & 5.5 & 2.2 \\
\hline $\mathrm{Lu}$ & 0.30 & 0.31 & & & & & \\
\hline $\mathrm{Hf}$ & 6.03 & 4.81 & & & & & \\
\hline $\mathrm{Ta}$ & 0.60 & 0.71 & & & & & \\
\hline W & 7.36 & 185.3 & & & & & \\
\hline $\mathrm{Pb}$ & 19.05 & 14.69 & 23.7 & 15.8 & 8.8 & 12.2 & 20.2 \\
\hline Th & 2.22 & 1.11 & 7 & 4.3 & 6.3 & 0.9 & 15,8 \\
\hline $\mathrm{U}$ & 0.57 & 0.17 & b.d.l.* & b.d.l. & 1.1 & b.d.l. & 1 \\
\hline $\mathrm{Nb}$ & 9.75 & 8.93 & b.d.l. & b.d.l. & b.d.1. & 32.5 & 37.6 \\
\hline $\mathrm{Be}$ & 2.22 & 2.07 & & & & & \\
\hline Cs & 1.27 & 0.79 & & & & & \\
\hline $\mathrm{Cu}$ & 14.32 & 44.96 & & & & & \\
\hline $\mathrm{Ga}$ & 22.59 & 21.3 & & & & & \\
\hline $\mathrm{Ge}$ & 1.5 & 1.41 & & & & & \\
\hline Mo & b.d.1. & 1.19 & & & & & \\
\hline $\mathrm{Sn}$ & 2.11 & 2.21 & & & & & \\
\hline$\sum$ REE & 194.89 & 173.79 & & & & & \\
\hline $\mathrm{K} / \mathrm{Rb}$ & 277 & 775 & 202 & 303 & 256 & 241 & 374 \\
\hline $\mathrm{Rb} / \mathrm{Sr}$ & 0.14 & 0.14 & 0.20 & 0.13 & 0.13 & 0.57 & 0.07 \\
\hline $\mathrm{Th} / \mathrm{U}$ & 3.88 & 6.49 & & & 5.73 & & 15.8 \\
\hline $\mathrm{Sr} / \mathrm{Y}$ & 24.23 & 23.50 & 19.89 & 10.14 & 26.19 & 3.03 & 21.64 \\
\hline $\mathrm{La}_{\mathrm{N}} / \mathrm{Yb}_{\mathrm{N}}$ & 11.28 & 9.54 & & & & 5.19 & 31.68 \\
\hline $\mathrm{Eu} / \mathrm{Eu}^{*}$ & 0.80 & 0.83 & & & & & \\
\hline
\end{tabular}


A. A. GANWA et al. / Int. J. Biol. Chem. Sci. 5(4): 1754-1767, 2011

Table 2a: Zircon evaporation data including radiogenic ${ }^{207} \mathrm{~Pb} /{ }^{206} \mathrm{~Pb}$ ratios and corresponding ages for sample Me.

\begin{tabular}{|c|c|c|c|c|c|c|c|}
\hline $\begin{array}{l}\text { Sample and } \\
\text { zircon } \mathbf{n}^{\circ}(\mathbf{a}, \mathrm{b} \\
=\text { Temp. step }\end{array}$ & $\begin{array}{l}\text { Evap. temp } \\
{ }^{\circ} \mathrm{C}\end{array}$ & $\begin{array}{l}\text { No of } \\
\text { ratios }\end{array}$ & $\begin{array}{l}\mathrm{U} / \mathrm{Th}^{*} \\
\text { ratio }\end{array}$ & $\begin{array}{l}{ }^{206} \mathrm{~Pb} /{ }^{208} \mathrm{P} \\
\text { b ratio }\end{array}$ & ${ }^{204} \mathrm{~Pb} /{ }^{206} \mathrm{~Pb}$ ratio & ${ }^{207} \mathrm{~Pb} /{ }^{206} \mathrm{~Pb}$ ratio & $\begin{array}{l}{ }^{207} \mathrm{~Pb} /{ }^{206} \mathrm{~Pb} \text { age } \\
\text { (Ma) } 2 \sigma \text { error }\end{array}$ \\
\hline Me-1a & 1400 & 187 & 1.11 & 3.58 & 0.000049 & $0.060406 \pm 048$ & $618.2 \pm 1.6$ \\
\hline Me-1b & 1420 & 139 & 1.55 & 4.98 & 0.000029 & $0.060394 \pm 053$ & $617.8 \pm 1.9$ \\
\hline $\mathrm{Me}-2 \mathrm{a}$ & 1420 & 140 & 2.32 & 8.25 & 0.000372 & $0.060594 \pm 101$ & $624.9 \pm 3.6$ \\
\hline $\mathrm{Me}-3 \mathrm{a}$ & 1400 & 126 & 2.44 & 7.98 & 0.000072 & $0.059935 \pm 023$ & $601.3 \pm 0.8$ \\
\hline $\mathrm{Me}-3 \mathrm{~b}$ & 1420 & 188 & 1.88 & 6.10 & 0.000054 & $0.060223 \pm 043$ & $611.7 \pm 1.6$ \\
\hline $\mathrm{Me}-4 \mathrm{a}$ & 1400 & 148 & 1.90 & 6.12 & 0.000042 & $0.060240 \pm 040$ & $612.2 \pm 1.4$ \\
\hline $\mathrm{Me}-4 \mathrm{~b}$ & 1420 & 185 & 1.92 & 6.60 & 0.000319 & $0.060193 \pm 042$ & $610.6 \pm 1.5$ \\
\hline Me-5a & 1380 & 100 & 2.01 & 6.57 & 0.000076 & $0.060706 \pm 654$ & $628.9 \pm 4.7$ \\
\hline Me-6a & 1380 & 118 & 1.82 & 5.91 & 0.000073 & $0.060155 \pm 071$ & $609.2 \pm 2.6$ \\
\hline Me-6b & 1420 & 223 & 1.78 & 5.88 & 0.000156 & $0.060265 \pm 054$ & $613.1 \pm 1.9$ \\
\hline \multicolumn{2}{|c|}{$\begin{array}{l}1 \mathrm{a}, 1 \mathrm{~b}, 2 \mathrm{a}, 3 \mathrm{~b}, 4 \mathrm{a}, 4 \mathrm{~b}, 5 \mathrm{a}, 6 \mathrm{a}, \\
6 \mathrm{~b} .\end{array}$} & 1554 & \multicolumn{4}{|c|}{$M S W D=0.53 ; \quad$ Probability $=0.85$} & $614.1 \pm 3.9$ \\
\hline
\end{tabular}


A. A. GANWA et al. / Int. J. Biol. Chem. Sci. 5(4): 1754-1767, 2011

Table 2b: Zircon evaporation data including radiogenic ${ }^{207} \mathrm{~Pb} /{ }^{206} \mathrm{~Pb}$ ratios and corresponding ages for sample ZGo1.

\begin{tabular}{|c|c|c|c|c|c|c|c|}
\hline $\begin{array}{l}\text { Sample and } \\
\text { zircon number } \\
\text { (a,b,c = Temp. } \\
\text { step }\end{array}$ & $\begin{array}{l}\text { Evap. } \\
\text { temp }{ }^{\circ} \mathrm{C}\end{array}$ & $\begin{array}{l}\text { No of } \\
\text { ratios }\end{array}$ & $\begin{array}{l}\mathrm{U} / \mathrm{Th}^{*} \\
\text { ratio }\end{array}$ & $\begin{array}{l}{ }^{206} \mathrm{~Pb} /{ }^{208} \mathrm{~Pb} \\
\text { ratio }\end{array}$ & $\begin{array}{l}{ }^{204} \mathrm{~Pb} /{ }^{206} \mathrm{~Pb} \\
\text { ratio }\end{array}$ & ${ }^{207} \mathrm{~Pb} /{ }^{206} \mathrm{~Pb}$ ratio & $\begin{array}{l}{ }^{207} \mathrm{~Pb} /{ }^{206} \mathrm{~Pb} \text { age } \\
\text { (Ma) } 2 \sigma \text { error }\end{array}$ \\
\hline ZGo1-2a & 1380 & 105 & 1.57 & 5.13 & 0.000115 & $0.060297 \pm 161$ & $614.3 \pm 5.8$ \\
\hline ZGo1-2b & 1400 & 112 & 1.53 & 4.92 & 0.000040 & $0.060519 \pm 084$ & $622.3 \pm 3.0$ \\
\hline Zgo1-2c & 1420 & 108 & 1.45 & 4.69 & 0.000040 & $0.060643 \pm 130$ & $626.6 \pm 4.6$ \\
\hline ZGo1-3a & 1410 & 114 & 1.59 & 5.20 & 0.000115 & $0.059406 \pm 210$ & $582.1 \pm 7.8$ \\
\hline ZGo1-3b & 1430 & 100 & 1.42 & 4.61 & 0,000115 & $0.059465 \pm 205$ & $584.2 \pm 7.6$ \\
\hline ZGo1-4a & 1400 & 112 & 1.55 & 5.17 & 0.000235 & $0.060429 \pm 151$ & $619.0 \pm 5.4$ \\
\hline ZGo1-4b & 1420 & 109 & 1.45 & 4.69 & 0.000071 & $0.060828 \pm 109$ & $633.2 \pm 3.9$ \\
\hline ZGo1-4c & 1440 & 107 & 1.50 & 4.87 & 0.000088 & $0.060477 \pm 133$ & $620.7 \pm 4.8$ \\
\hline ZGo1-5a & 1400 & 70 & 1.16 & 3.75 & 0.000073 & $0.060657 \pm 226$ & $627.1 \pm 8.1$ \\
\hline \multicolumn{2}{|c|}{$\begin{array}{l}\text { Mean } \\
2 a, 2 b, 2 c, 3 a, 3 b, 4 a, 4 b, 4 c \\
5 a\end{array}$} & 937 & & \multicolumn{3}{|c|}{ MSWD $=0.87 ; \quad$ Probability $=0.54$} & $619.8 \pm 9.8$ \\
\hline
\end{tabular}




\section{DISCUSSION}

Implications from geochemistry

The studied samples displayed chemical characteristics of medium-K calc-alkaline to shoshonitic granitoids and possessed I-type features as defined by Chappell and White (1974) and Chappell and Stephens (1988). They have a very weak anomaly negative $\mathrm{Eu}$ due to minor fractionation of plagioclase or to the fact that the parental magma of the diorite was in equilibrium with a plagioclase-bearing mantle source. The heavy-REE concentration of 10 to 20 times chondritic shows that garnet was absent from the original source. The negative anomalies in $\mathrm{Nb}, \mathrm{Ta}, \mathrm{Ti}$ and positive anomaly in $\mathrm{K}$ reflect geochemical source characteristics of the metadiorite protolith and provide evidence for the contribution of continental crustal material to the magma source (Taylor and McLennan, 1985; Barbarin, 1999). Negative Nb-Ta-Ti anomalies attest a subduction zone environment in which this crust was formed originally but these geochemical features are often retained during crustal reprocessing and can also be found in collisional-type granitoids (Pearce et al., 1984).

The syn-D2 emplacement and the ${ }^{207} \mathrm{~Pb} /{ }^{206} \mathrm{~Pb}$ ages indicate that this pluton dates the D2 deformation phase. The D2 event is thus interpreted to have occurred between 619 $\pm 9.8 \mathrm{Ma}$ and $614 \pm 3.9 \mathrm{Ma}$ in the Méiganga region.

\section{Regional timing of the D2 deformation event}

D2 deformation and coeval magmatism in the Panafrican fold belt in Cameroon was dated at $600-580 \mathrm{Ma}$ by Toteu et al. (1987, 2001). The Méiganga metadiorite gives similar older ages within the error limit to the ages obtained for granites from eastern Cameroon $(614 \pm 41 \mathrm{Ma}$ and $621 \pm 15 \mathrm{Ma}$, Rb-Sr whole-rock isochron: Soba et al., 1991). A similar age of $615 \pm 27 \mathrm{Ma}$ (U-Th-Pb monazite) has been obtained for a biotite muscovite granite in the north of Ngaoundéré which was syn- to late-tectonically emplaced relative to D2 (Tchameni et al., 2006). Syntectonic D2 granitoids in Tibati area, 300 $\mathrm{km}$ west of Méiganga, yield a U-Pb zircon age of $620 \pm 30 \mathrm{Ma}$ (Nzenti et al., 2006). SynD2 granitoids of western Cameroon were dated at 609-557 Ma (Kwékam et al., 2010; Nguiessi-Tchankam et al., 1994, 1997; Talla, 1995; Tagne-Kamga, 2003). This age is close to that of the syn-D3 granites dated at 601-558 Ma in the Méiganga area (Ganwa, 2005). All these rocks are characterized by discrete magmatic foliation and weak solid-state deformation, as opposed to the Méiganga metadiorite which shows the same penetrative solid-state deformation as the host gneisses. Nevertheless, we cannot completely rule out that granitoids of different age were generated in response to the same regional tectonomagmatic process. The D2 event could have started earlier in the Méiganga and Tibati areas and might have progressed southwestward to the western Cameroon area. Such scenario would be in line with the collision model of Ngako et al. (2008) in which the Saharan rigid prong penetrated into the São Francisco-Congo Craton between 640 and $580 \mathrm{Ma}$ and generated intense deformation in northwestern Cameroon. In this case, the D2 deformational phase was diachronic in the Adamawa-Yade Domain of the CAFB. Diachronism in the tectonomagmatic event has been also demonstrated in the Macururé Domain of the Sergipano Belt (Bueno et al., 2009) in the Borborema Province (NE Brazil). Such similarities suggest that NE Brazil and Central Africa underwent the same tectonomagmatic history during the Neoproterozoic era.

\section{ACKNOWLEDGEMENTS}

The German Academic Exchange Service (DAAD) is highly acknowledged for supporting the research stay of the first author (GAA) at the University of Tübingen (Germany). The anonymous reviewers are thanked for their constructive remarks. 


\section{REFERENCES}

Altherr R, Holl A, Hegner E, Langer C, Kreuzer H. 2000. High-potassium, calcalkaline I-type plutonism in the European Variscides: northern Vosges (France) and northern Schwarzwald (Germany). Lithos, 50: 51-73.

Barbarin B. 1999. A review of the relationships between granitoid types, their origins and geodynamic environments. Lithos, 46: 605-626.

Bueno JF, Oliveria EP, McNaughton NJ, Laux JH. 2009. U-Pb dating of granites in the Neoproterozoic Sergipano Belt, NEBrazil: Implications for the timing and duration of continental collision and extrusion tectonics in the Borborema province. Gondwana Research, 15: 8697.

Chappell BW, Stephens WE. 1988. Origin of infracrustal (I-type) granite magmas. Transactions of the Royal Society of Edinburgh: Earth Sciences, 79: 71-86.

Chappell BW, White AJR. 1974. Two contrasting granite types. Pacific Geology, 8: 173-174.

Chen F, Siebel W, Satir M. 2002. Zircon U$\mathrm{Pb}$ and $\mathrm{Pb}$-isotope fractionation during stepwise HF-acid leaching and chronological implications. Chemical Geology, 191: 155-164.

Cocherie A, Guerrot C, Rossi P. 1992. Singlezircon dating by stepwise $\mathrm{Pb}$ evaporation: Comparison with other geochronological techniques applied to the Hercynian granites of Corsica, France. Chemical Geology, 101: 131141.

Djouka-Fonkwé ML, Schulz B, Schüssler U, Tchouankoué J-P, Nzolang C. 2007. Geochemistry of the Bafoussam PanAfrican I- and S-type granitoids in western Cameroon, Journal of African Earth Sciences, 50: 148-167.

Ganwa AA. 2005. Les granitoïdes de Méiganga: étude pétrographique, géochimique, structurale et géochronologique. Leur place dans la chaîne panafricaine. Thèse de Doctorat d'État, Université de Yaoundé I, 162 pp.

Kober B. 1986. Whole grain evaporation for $207 \mathrm{~Pb} / 206 \mathrm{~Pb}$-age investigations on single zircons using a double-filament thermal ion source. Contribution to Mineralogy and Petrology, 93: 482-490.

Kober B. 1987. Single zircon evaporation combined with $\mathrm{Pb}+$ emitter bedding for $207 \mathrm{~Pb} / 206 \mathrm{~Pb}$-age investigations using thermal ion mass spectrometry, and implications in zirconology. Contribution to Mineralogy and Petrology, 96: 63-71.

Kröner A, Willner AP. 1998. Time of formation and peak of Variscan HP-HT metamorphism of quartz-feldspar rocks in the central Erzgebirge, Saxony, Germany. Contribution to Mineralogy and Petrology, 132: 1-20.

Kwékam M, Liégeois J-P, Njonfang E, 1 Affaton P, Hartmann G, Tchoua F. 2010. Nature, origin and significance of the Fomopéa Pan-African high-K calcalkaline plutonic complex in the Central African fold belt (Cameroon). Journal of African Earth Sciences, 57: 79-95

Lasserre M. 1961. Etude géologique de la partie orientale de l'Adamaoua (Cameroun Central) et les principales sources minéralisées de l'Adamaoua. Bulletin de la Direction des Mines et Géologie du Cameroun, 4: 131.

Mc Donough WF, Sun SS. 1995. The composition of the Earth. Chemical Geology, 120: 223-253.

McDonough WF, Sun SS, Ringwood AE, Jagoutz E, Hofmann AW. 1992. Potassium, rubidium and cesium in the Earth and Moon and the evolution of the mantle of the Earth. Geochimica et Cosmochimica Acta, 56: 1001-1012.

Ngako V, Affaton P, Njonfang E. 2008. PanAfrican tectonics in northwestern Cameroon: Implication for the history of western Gondwana. Gondwana Research, 14: 509-522. 
Nguiessi-Tchankam C, Nzenti J-P, Nsifa EN, Tempier P, Tchoua FM. 1997. Les granitoïdes calco-alcalins, syncisaillement de Bandja dans la chaîne panafricaine nord équatoriale au Cameroun. Comptes Rendus de l'Académie Sciences, 325: 95-101.

Nguiessi-Tchankam C, Vialette Y. 1994. Données géochronologiques $(\mathrm{Rb}-\mathrm{Sr}, \mathrm{Pb}-$ $\mathrm{Pb}, \mathrm{U}-\mathrm{Pb}$ ) sur le complexe plutonique de Bandja (Centre-Ouest Cameroun). Comptes Rendus de l'Académie Sciences, 319: 317-324.

Njanko T, Nédélec A, Affaton P. 2006. Synkinematic high-K calc-alkaline plutons associated with the Pan-African Central Cameroon shear zone (W-Tibati area): Petrology and geodynamic significance. Journal African Earth Sciences, 44: 494510.

Njanko T, Nédélec A, Kwékam M, Siqueira R, Esteban L. 2010. Emplacement and deformation of the Fomope'a pluton: Implication for the Pan-African history of Western Cameroon. Journal of Structural Geology, xxx : 1-15.

Nzenti JP. 1994. L'Adamaoua panafricain (région de Banyo) une zone clé pour un modèle géodynamique de la chaîne panafricaine nord équatoriale au Cameroun. Thèse Doctorat d'Etat Univ. Cheick Anta Diop-Univ de Nancy I, 176 pp.

Nzenti JP, Badibanga Kapajika, Worner G, Lubala Toto R. 2006. Syn-kinematic emplacement of granitoids in a PanAfrican shear zone in Central Cameroon. Journal African Earth Sciences, 45: 7486.

Nzolang C, Kagami H, Nzenti JP, Holtz F. 2003. Geochemistry and preliminary $\mathrm{Sr}-$ $\mathrm{Nd}$ isotopic data on the Neoproterozoic granitoids from the Bantoum area, west Cameroon: evidence for a derivation from a Paleoproterozoic Archean crust. Polar Geoscience, 16: 196-226.
Pearce JA, Harris NBW, Tindle AG. 1984. Trace element discrimination diagrams for the tectonic interpretation of granitic rocks. Journal of Petrology, 25: 956983.

Penaye J, Toteu SF, Michard A, Bertrand JM, Dautel D. 1989. Reliques granulitiques d'âge protérozoïque inférieur dans la zone mobile panafricaine d'Afrique centrale au Cameroun: géochronologie $\mathrm{U}-\mathrm{Pb}$ sur zircons. Comptes Remndus Académie Sciences, 309: 315-318.

Rickwood PC. 1989. Boundary lines within petrologic diagrams which use oxides of major and minor elements. Lithos, 22: 247-264.

Siebel W, Blaha U, Chen F, Rohrmüller J. 2005. Geochronology and geochemistry of a dyke-host rock association and implications for the formation of the Bavarian Pfahl shear zone, Bohemian Massif. International Journal of Earth Sciences, 94: 8-23.

Soba D, Michard A, Toteu SF, Norman DI, Penaye J, Ngako V, Nzenti J-P, Dautel D. 1991. Données géochronologiques nouvelles ( $\mathrm{Rb}-\mathrm{Sr}, \mathrm{U}-\mathrm{Pb}, \mathrm{Sm}-\mathrm{Nd}$ ) sur la zone mobile panafricaine de 1'Est Cameroun: âge Protérozoïque supérieur de la série de Lom. Comptes rendus de l'Académie des Sciences 315: 14531458.

Tagne-Kamga G. 2003. Petrogenesis of the Neoproterozoic Ngondo Plutonic complex (Cameroon, west central Africa): a case of late-collisional ferropotassic magmatism. Journal of African Earth Sciences, 36: 149-171.

Tagne-Kamga G, Mercier E, Rossy M, Nsifa NE. 1999. Syn-kinematic emplacement of the Pan-African Ngondo igneous complex (west Cameroon, central Africa). Journal of African Earth Sciences, 28: 675-691.

Talla V. 1995. Le Massif granitic panafricain de Batié (Ouest - Cameroun): Pétrologie 
-Pétrostructurale - Géochimie. Ph.D Thesis, University of Yaoundé I, 144 pp.

Taylor, RS, McLennan SM. 1985. The Continental Crust: its Composition and Evolution. Blackwell: Oxford; 312.

Tchameni R, Pouclet A, Penaye J, Ganwa AA, Toteu SF. 2006. Petrography and geochemistry of the Ngaoundéré PanAfrican granitoids in Central North Cameroon: Implications for their sources and geological setting. Journal of African Earth Sciences, 44: 511-529.

Toteu SF, Michard A, Bertrand JM, Rocci G. 1987. U/Pb dating of Precambrian rocks from northern Cameroon, orogenic evolution and chronology of the Panafrican belt of Central Africa. Precambrian Research, 37: 71-87.

Toteu SF, Van Schmus WR, Penaye J, Michard A. 2001. New U-Pb and Sm$\mathrm{Nd}$ data from north-central Cameroon and its bearing on the pre-Pan African history of central Africa. Precambrian Research, 108: 45-73.

Toteu SF, Penaye J, Poudjom Djomani Y. 2004. Geodynamic evolution of the panAfrican belt in central Africa with special reference to Cameroon. Canadian Journal of Earth Sciences, 41: 73-85.

Wiedenbeck M, Alle P, Corfu F, Griffin WL, Meier M, Oberli F, Von Quadt A, Roddick JC, Spiegel W. 1995. Three natural zircon standards for $\mathrm{U}-\mathrm{Th}-\mathrm{Pb}$, Lu-Hf, trace element and REE analyses, Geostandard Newsletters, 19: 1-23.

Wilson M. 1989. Igneous Petrogenesis. Unwin Hyman: London. 